\title{
Crystallography of hornblende amphibole in LAP04840 $R$ chondrite and implication for its metamorphic history
}

\author{
Kouhei OтA ${ }^{*}$, Takashi MikouchI ${ }^{*}$ and Kazumasa SugiYama ${ }^{* *}$ \\ *Department of Earth and Planetary Science, Graduate School of Science, \\ The University of Tokyo, 7-3-1 Hongo, Bunkyo-ku, Tokyo 113-0033, Japan \\ **Institute for Materials Research, Tohoku University, \\ 2-1-1 Katahira, Aoba-ku, Sendai 980-8577, Japan
}

\begin{abstract}
LAP04840 is an unusual R chondrite that includes abundant hornblende amphibole. LAP04840 shows a texture of equilibrated chondrite composed of $59.3 \%$ olivine, $13.5 \%$ orthopyroxene, $13.3 \%$ hornblende, $6.2 \%$ plagioclase, $6.0 \% \mathrm{Fe}-\mathrm{Ni}$ sulfide, and $1.7 \%$ accessory minerals. Hornblende replaces olivine and pyroxene in both chondrules and matrices, suggesting its secondary origin. All major phases in LAP04840 are homogeneous: olivine $\left(\mathrm{Fa}_{37}\right)$, orthopyroxene $\left(\mathrm{En}_{70} \mathrm{Wo}_{1}\right)$, and plagioclase $\left(\mathrm{An}_{8} \mathrm{Or}_{2}\right)$. Hornblende is also nearly homogeneous, but the total sum by electron microprobe analysis is $96-98 \mathrm{wt} \%$, suggesting the presence of $\mathrm{Fe}^{3+}$ and a hydroxyl group. Synchrotron $\mathrm{Fe}-\mathrm{XANES}$ analysis gives a $\mathrm{Fe}^{3+} / \Sigma \mathrm{Fe}$ ratio of $\sim 0.6$ and micro-FT-IR analysis confirms the presence of a hydroxyl group. Thus, the structural formula is $\left(\mathrm{Na}_{0.40} \mathrm{~K}_{0.04}\right)\left(\mathrm{Ca}_{1.46} \mathrm{Mn}_{0.02} \mathrm{Fe}_{0.06}^{2+} \mathrm{Na}_{0.46}\right)\left(\mathrm{Al}_{0.08} \mathrm{Fe}_{0.43}^{2+}\right.$ $\left.\mathrm{Fe}_{0.75}^{3+} \mathrm{Cr}_{0.08} \mathrm{Mg}_{3.60}\right)\left(\mathrm{Si}_{7.02} \mathrm{Al}_{0.98}\right) \mathrm{O}_{22}(\mathrm{OH})_{2}$. Single crystal X-ray diffraction of LAP04840 hornblende gives the following lattice constants: $a=9.7957(9) \AA, b=18.0788(12) \AA, c=5.2949(5) \AA, \beta=104.747(3)^{\circ}$. The relatively short distances of $\left[\mathrm{M}(1)^{-} \mathrm{O}=2.069 \AA\right],[\mathrm{M}(2)-\mathrm{O}=2.081 \AA]$, and $\left[\mathrm{M}(3)^{-} \mathrm{O}=2.058 \AA\right]$ suggest the feasible preference of small $\mathrm{Fe}^{3+}$ at these sites. The mineralogy and petrology of LAP04840 are consistent with its classification as an R6 chondrite. However, the presence of hornblende and biotite is quite unique among not only R chondrites but also asteroidal meteorites in general. The presence of these hydrous minerals suggests metamorphism under high pressure and an aqueous environment probably at depth in the parent body. A thermometer using hornblende and plagioclase equilibria gives $T=670-690{ }^{\circ} \mathrm{C}$. Further, a barometer using $\mathrm{Al}$ content in hornblende gives $P=\sim 0.1 \mathrm{GPa}$. Although these estimates bear some uncertainties, it is likely that the size of the R chondrite parent body was large enough to induce such metamorphism.
\end{abstract}

Keywords: R chondrite, Hornblende, Biotite, Albite, Micro-XANES, XRD, Hydrothermal metamorphism

\section{INTRODUCTION}

Although the amphibole group is one of the major rockforming minerals in the earth, it rarely occurs in extraterrestrial samples. This is mainly because extraterrestrial samples, especially meteorites, were formed under low pressure and anhydrous conditions, where amphiboles are not stable. Martian meteorites are the only meteorite group that commonly contains amphiboles because some of these meteorites are believed to have been formed at a depth where kaersutite amphibole is stable (e.g., Johnson et al., 1991; McSween, 2002). However, Martian amphibole occurs as only minute grains (up to several tens of $\mu \mathrm{m}$ ) with very low abundance (modal abundance $<0.1 \%$ ). They are present exclusively in magmatic inclusions (usu-

doi:10.2465/jmps.080903

T. Mikouchi, mikouchi@eps.s.u-tokyo.ac.jp Corresponding author ally less than several hundreds of $\mu \mathrm{m}$ in diameter) of pyroxene and olivine grains from shergottites and chassignites (e.g., Johnson et al., 1991; Mikouchi and Miyamoto, 2000; Monkawa et al., 2006). Martian amphibole is Ti-rich kaersutite, which is distinct from terrestrial kaersutite (Monkawa et al., 2006). Furthermore, the presence of kaersutite in Martian meteorites has provided important information about water content in primary Martian magmas (e.g., Johnson et al., 1991).

LaPaz Icefield 04840 (LAP04840) is a $50 \mathrm{~g}$ meteorite recently discovered in Antarctica that is classified as a member of the Rumuluti (R) chondrite group (Antarct. Meteorite Newslett., 2006). R chondrite is one of the major chondrite groups and is known to have formed under relatively oxidizing conditions (e.g., Brearley and Jones, 1998). Although $\mathrm{R}$ chondrites are petrologically similar to ordinary chondrites, their unusual oxygen isotope compo- 
sitions may suggest that the $\mathrm{R}$ chondrite parent body is formed at a greater heliocentric distance than ordinary chondrites (e.g., Kallemeyn et al., 1996). LAP04840 is an unusual $\mathrm{R}$ chondrite that includes abundant large hornblende amphibole grains (e.g., Mikouchi et al., 2007; Treiman et al., 2007) because constituent phases of previously known $\mathrm{R}$ chondrites are all anhydrous minerals including olivine, pyroxene, plagioclase, and $\mathrm{Fe}-\mathrm{Ni}$ sulfide (e.g., Brearley and Jones, 1998). LAP04840 is the first meteorite ever found that contains such abundant amphibole grains. The presence of abundant large amphibole grains in LAP04840 is unique, thus offering useful information about the formation of this meteorite and its parent body. Furthermore, detailed crystal chemistry of extraterrestrial amphibole has never been reported. Therefore, it is of great interest to know its crystal chemistry in comparison with terrestrial amphiboles in order to better understand the crystallography of this complex mineral group.

In this paper, we report the petrology and mineralogy of LAP04840 by especially paying attention to the crystallography of hornblende and discuss the formation condition of $\mathrm{R}$ chondrite by using geothermobarometers applied to constituent phases in LAP04840.

\section{SAMPLE AND EXPERIMENTS}

\section{Sample}

A thin section (LAP04840,22) and a small rock chip $(0.398 \mathrm{~g}$ : LAP04840,13) of LAP04840 were provided by the Meteorite Working Group (MWG) from the US Antarctic meteorite collection. The thin section was used for general petrographic observation by optical and electron microscopy. Electron microprobe and synchrotron microXANES analyses were also performed on this thin section. Single crystals of hornblende extracted from a small rock chip were used for single crystal X-ray diffraction and micro-FT-IR analyses.

\section{Electron beam analyses}

Backscattered electron (BSE) images were taken with a Hitachi S-4500 (field emission gun) scanning electron microscope (SEM) with energy dispersive spectrometers (EDS). This SEM is equipped with an electron back-scattering diffraction (EBSD) detector, which was used for phase identification of the thin section. Elemental distribution maps were acquired by a JEOL JXA 8900L electron microprobe to observe mineral distributions on the thin section, and the resulting $10 \times 5 \mathrm{~mm}$ map was used to deduce the modal abundance of constituent phases. The accelerating voltage was $15 \mathrm{kV}$ and beam current was 60 nA. Quantitative wavelength dispersive analyses were performed on JEOL JCM $733 \mathrm{mk}$ II and JEOL JXA 8900L microprobes by using well-characterized natural and synthetic standards. Quantitative microprobe analyses of most phases were obtained at an accelerating voltage of $15 \mathrm{kV}$ with a beam current of $12 \mathrm{nA}$ on a Faraday cage. A defocused beam $(\sim 5 \mu \mathrm{m}$ in diameter) and lower probe current $(8 \mathrm{nA})$ were employed for the analysis of albite, hornblende, and biotite to minimize volatile loss. Analysis of $\mathrm{Fe}-\mathrm{Ni}$ sulfides was performed at an accelerating voltage of $25 \mathrm{kV}$ and beam current of $20 \mathrm{nA}$.

Due to our special interest in hornblende, we also employed the following techniques to further characterize hornblende in LAP04840.

\section{Micro-XANES analysis}

XANES spectra at the Fe $K$-absorption edge were measured by using a synchrotron radiation (SR) source and a $\mathrm{Si}$ (Li)-Solid State Detector (SSD) at BL-4A, Photon Factory (PF), Institute of Material Structure Science (IMSS), High Energy Accelerator Research Organization (KEK), Tsukuba, Japan. The SR X-ray was monochromatized with a $\mathrm{Si}$ (111) double-crystal monochromator. Microfocusing Kirkpatrick-Baez mirrors were used to focus the incident X-ray beam of about $10 \mu \mathrm{m}$ in diameter at the specimen position (Iida, 1997). An ionization chamber was used to monitor the X-ray incidence irradiating a crystal specimen, and the SSD was mounted at about $90^{\circ}$ to the incident beam within the photon polarization plane. The XANES spectra at the $\mathrm{Fe} K$-absorption edge were obtained in the fluorescence mode by scanning the incident X-ray energy from 7103 to $7153 \mathrm{eV}$ at an interval of $0.13 \mathrm{eV}$. The obtained pre-edge centroid position of the LAP04840 hornblende was compared with that of standard monoclinic amphibole samples of kaersutite from Kaersut (Qaersut), Umanq District, Greenland (KST), and Iki Island, Nagasaki Prefecture, Japan (IKI), with known $\mathrm{Fe}^{3+} / \Sigma \mathrm{Fe}$ ratios measured by wet chemistry (Monkawa et al., 2006). It may be added that the incident $X$-ray energy was calibrated by observing the first inflection point of the Fe $K$-edge of a metallic Fe foil at $7111.08 \mathrm{eV}$ (Wilke et al., 2001). Crystal orientation is a major factor affecting the resultant XANES profile. Therefore, we analyzed hornblende grains that have clear elongated dimensions matching with the standard amphibole samples.

\section{Micro-FT-IR spectroscopy}

In order to qualitatively estimate the hydroxyl group content of hornblende, micro-FT-IR spectra of LAP08480 


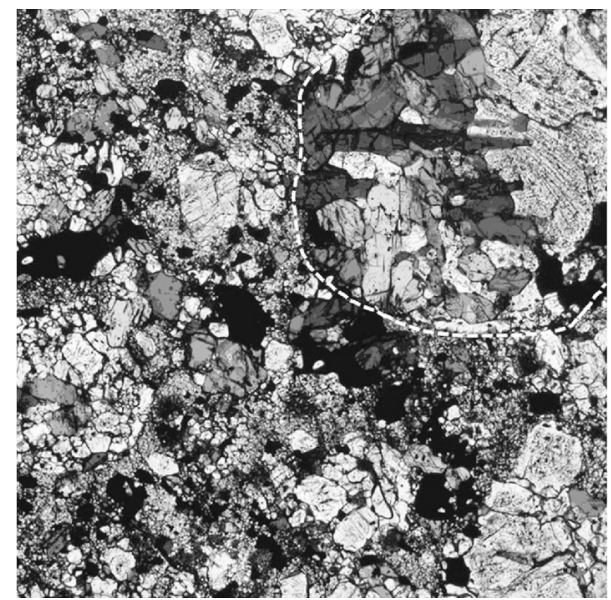

Figure 1. Optical photomicrograph of LAP04840 (plane-polarized light). The section is mainly composed of olivine, orthopyroxene, hornblende, plagioclase, magnetite, and Fe-Ni sulfide. Grayish grains are hornblende. A dashed line at the upper right corner shows a chondrule which is partially replaced by large hornblende grains. The field of view is $2.2 \mathrm{~mm}$.

hornblende were measured by using a JASCO IRM-3000 infrared microscope. We picked up single crystals of hornblende removed from a small rock chip of LAP04840 (LAP04840,13) for this measurement. The areas of about $20 \times 20 \mu \mathrm{m}$ of the thin grains were measured for transmission-reflection spectra in the range of $4000-650 \mathrm{~cm}^{-1}$ after extracted crystals were pressed between $\mathrm{KBr}$ plates.

\section{Single crystal structural analysis}

A single crystal hornblende with dimensions of $0.076 \times$ $0.095 \times 0.135 \mathrm{~mm}$ was attached to a glass fiber and mounted on an X-ray diffractometer equipped with an imaging plate and a sealed X-ray tube (Rigaku RAXISRAPID). Intensity patterns observed by monochromated MoKa radiation lead to a monoclinic cell with the space group $C 2 / m$, and no streaking or subsidiary intensity maxima were observed. An ordinary oscillation technique was applied and 4555 reflections were measured so as to cover a hemisphere of the reciprocal space up to a resolution of $0.70 \AA$. After Lorentz and polarization corrections, absorption correction was performed by using the integration method on the basis of the observed arbitrary shape of the specimen (Higashi, 1995). The maximum and minimum transmission factors were $89.6 \%$ and $83.0 \%$, respectively. Data reduction yielded 1410 independent reflections $\left[R_{\text {int }}(I)=0.0334\right]$, among which 1005 reflections met the condition of $I_{o b s .}>2.0 \sigma\left(I_{o b s .}\right)$. Scattering factors for neutral atoms together with anomalous dispersion coefficients were taken from International Tables Volume C (1992). Atomic coordinates and equivalent isotropic tem-
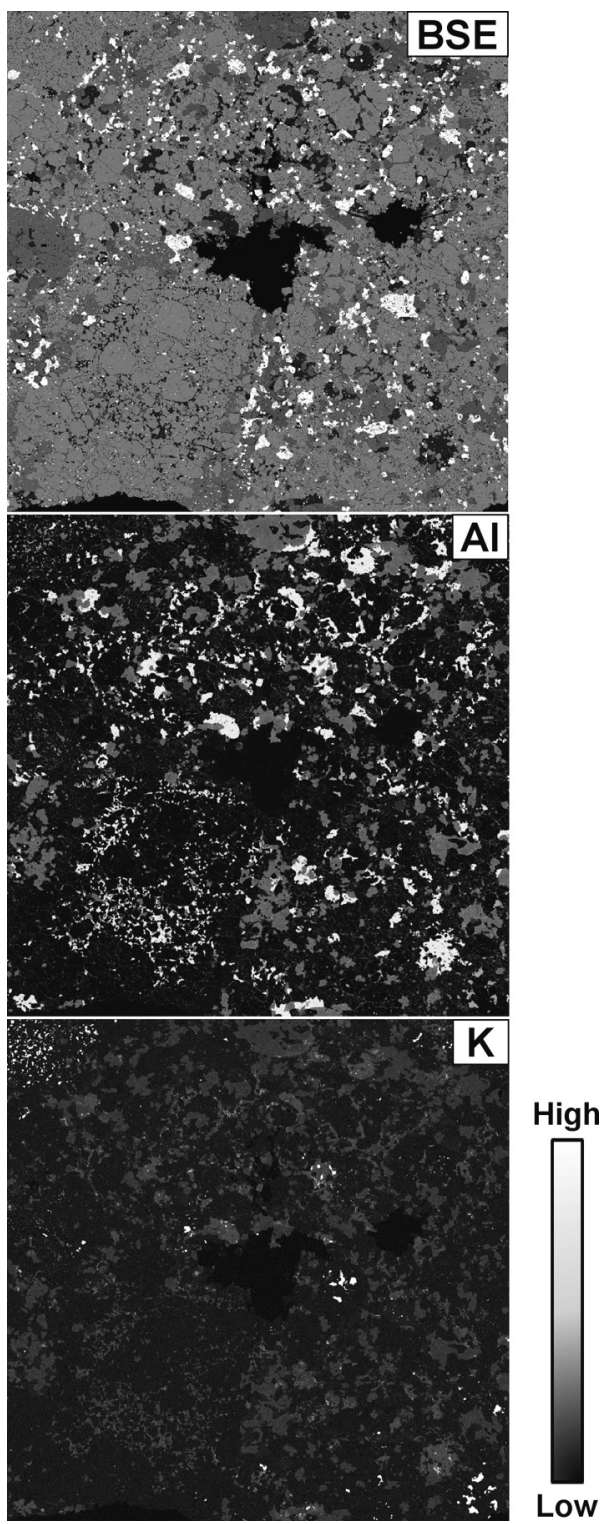

Figure 2. BSE and X-ray maps (Al and K) of LAP04840. Bright phases in the BSE image are $\mathrm{Fe}-\mathrm{Ni}$ sulfides and $\mathrm{Cr}$-rich magnetite. Bright areas in the $\mathrm{Al}$ map are albitic plagioclase. The second brightest phase in the $\mathrm{Al}$ map is hornblende. They are usually closely associated. In the $\mathrm{K}$ map, biotite grains are shown as bright spots. The field of view of all images is $6 \mathrm{~mm}$.

perature factors of magnesio-hornblende (Oberti et al., 1995) were used as initial parameters for the least-squares refinement of SHELXL97 (Sheldrick, 1997).

\section{RESULTS}

\section{Petrography}

LAP04840 shows a texture of equilibrated chondrite composed of $59.3 \%$ olivine, $13.5 \%$ orthopyroxene, $13.3 \%$ hornblende, $6.2 \%$ plagioclase, $6.0 \% \mathrm{Fe}-\mathrm{Ni}$ sulfide, $0.7 \%$ 
Table 1. Electron microprobe analysis of major and minor phases in LAP04840

\begin{tabular}{|c|c|c|c|c|c|c|c|c|c|}
\hline & Olivine & Orthopyroxene & Hornblende & Plagioclase & $\begin{array}{l}\text { Cr-rich } \\
\text { magnetite }\end{array}$ & Biotite & & $\begin{array}{l}\text { Ni-rich } \\
\text { pyrrhotite }\end{array}$ & Pentlandite \\
\hline $\mathrm{SiO}_{2}$ & 36.3 & 54.5 & 49.5 & 66.9 & 0.09 & 39.3 & $\mathrm{Fe}$ & 53.2 & 30.8 \\
\hline $\mathrm{Al}_{2} \mathrm{O}_{3}$ & 0.03 & 0.14 & 6.31 & 0.3 & 2.29 & 13.6 & $\mathrm{Ni}$ & 7.90 & 33.9 \\
\hline $\mathrm{TiO}_{2}$ & 0.01 & 0.04 & 0.44 & 0 & 1.34 & 0.97 & Co & 0.33 & 1.01 \\
\hline $\mathrm{FeO}^{*}$ & 32.6 & 18.6 & 10.8 & 0.27 & 67.5 & 11.7 & $\mathrm{~S}$ & 38.1 & 32.5 \\
\hline $\mathrm{MnO}$ & 0.40 & 0.45 & 0.14 & 0 & 0.20 & 0.02 & & & \\
\hline $\mathrm{MgO}$ & 30.7 & 25.2 & 17.1 & 0 & 1.85 & 19.3 & & & \\
\hline $\mathrm{CaO}$ & 0.02 & 0.47 & 9.61 & 1.65 & 0 & 0.01 & & & \\
\hline $\mathrm{Na}_{2} \mathrm{O}$ & 0 & 0 & 3.14 & 10.1 & 0.02 & 1.94 & & & \\
\hline $\mathrm{K}_{2} \mathrm{O}$ & 0.01 & 0 & 0.24 & 0.40 & 0.07 & 7.45 & & & \\
\hline $\mathrm{Cr}_{2} \mathrm{O}_{3}$ & 0.07 & 0.08 & 0.68 & 0.01 & 19.3 & 0.82 & & & \\
\hline $\mathrm{V}_{2} \mathrm{O}_{3}$ & 0 & 0.03 & 0 & 0 & 0.23 & 0.09 & & & \\
\hline $\mathrm{NiO}$ & 0.41 & 0.08 & 0 & 0 & 0.21 & 0.32 & & & \\
\hline $\mathrm{P}_{2} \mathrm{O}_{5}$ & 0.01 & 0.02 & 0 & 0 & 0 & 0 & & & \\
\hline $\mathrm{Cl}$ & & & 0 & & & 0.06 & & & \\
\hline $\mathrm{F}$ & & & 0 & & & 0 & & & \\
\hline Total & 100.6 & 99.6 & 98.0 & 99.6 & 93.1 & 95.9 & & 99.5 & 98.2 \\
\hline Fo & 62.7 & & & & & & & & \\
\hline $\mathrm{Fa}$ & 37.3 & & & & & & & & \\
\hline En & & 70.1 & & & & & & & \\
\hline Fs & & 29.0 & & & & & & & \\
\hline Wo & & 0.9 & & & & & & & \\
\hline An & & & & 8.1 & & & & & \\
\hline $\mathrm{Ab}$ & & & & 89.5 & & & & & \\
\hline Or & & & & 2.4 & & & & & \\
\hline
\end{tabular}

A All Fe as $\mathrm{Fe}^{2+}$.

Cr-rich magnetite, $0.5 \%$ biotite, and $0.5 \%$ Ca phosphate (Figs. 1 and 2). Although most R chondrites are brecciated, LAP04840 does not show a typical brecciated texture (e.g., Brearley and Jones, 1998). Chondrules and chondrule fragments are spatially distributed with sizes of up to $1.5 \mathrm{~mm}$ in diameter. Several different types of chondrules are observed. Matrices are composed of finegrained granular areas $(5-10 \mu \mathrm{m}$ in grain size $)$ with isolated mineral fragments of usually $100-200 \mu \mathrm{m}$ in size. Hornblende with strong pleochroism occurs, replacing olivine and pyroxene in both chondrules and matrices as shown in Figure 1. Such an occurrence of hornblende suggests that it has a secondary origin after the formation of chondrules and matrices accumulated in the parent body. Fe-Ni sulfide is scattered throughout the thin section, and its size ranges from $\sim 1 \mu \mathrm{m}$ (usually spherical inclusions in almost all other phases) to $100 \mu \mathrm{m}$ (irregular-shaped interstitial grains). It may be noted that biotite is a minor component, but its occurrence is generally similar to hornblende since biotite is present both in chondrules and matrices and sometimes replaces primary olivine and pyroxene (Fig. 2). The shock effect is not so obvious although some pyroxene and plagioclase grains show undulatory extinction under an optical microscope. This observation is consistent with the sharp diffraction patterns of hornblende by single crystal X-ray diffraction analysis.

\section{Mineral compositions}

All the constituent mineral phases in LAP04840 have nearly uniform chemical compositions (Table 1). Olivine in LAP04840 is equilibrated $\left(\mathrm{Fa}_{37}\right)$. Olivine contains small amounts of $\mathrm{Ca}(<0.2 \mathrm{wt} \% \mathrm{CaO})$ and $\mathrm{Cr}\left(<0.3 \mathrm{wt} \% \mathrm{Cr}_{2} \mathrm{O}_{3}\right)$, but $\mathrm{Ni}$ abundance is high $(\sim 0.5 \mathrm{wt} \% \mathrm{NiO})$, suggesting formation under a relatively oxidizing condition. This high Ni content in olivine is consistent with the absence of $\mathrm{Fe}-\mathrm{Ni}$ metal in this meteorite. Pyroxene is orthopyroxene with a homogeneous composition $\left(\mathrm{En}_{70} \mathrm{Wo}_{1}\right)$. No Carich pyroxenes were found in LAP04840. Hornblende is generally homogeneous as indicated by a relatively small compositional range. There is no clear heterogeniety in the chemical composition among different mineral grains as well as in the individual grains, and the compositional range is $47-50 \mathrm{wt} \% \mathrm{SiO}_{2}, 5-8 \mathrm{wt} \% \mathrm{Al}_{2} \mathrm{O}_{3}, 0.2-0.6 \mathrm{wt} \%$ $\mathrm{TiO}_{2}, 10-13 \mathrm{wt} \% \mathrm{FeO}$ (all $\mathrm{Fe}$ as $\mathrm{Fe}^{2+}$ ), 16-18 wt $\% \mathrm{MgO}$, 


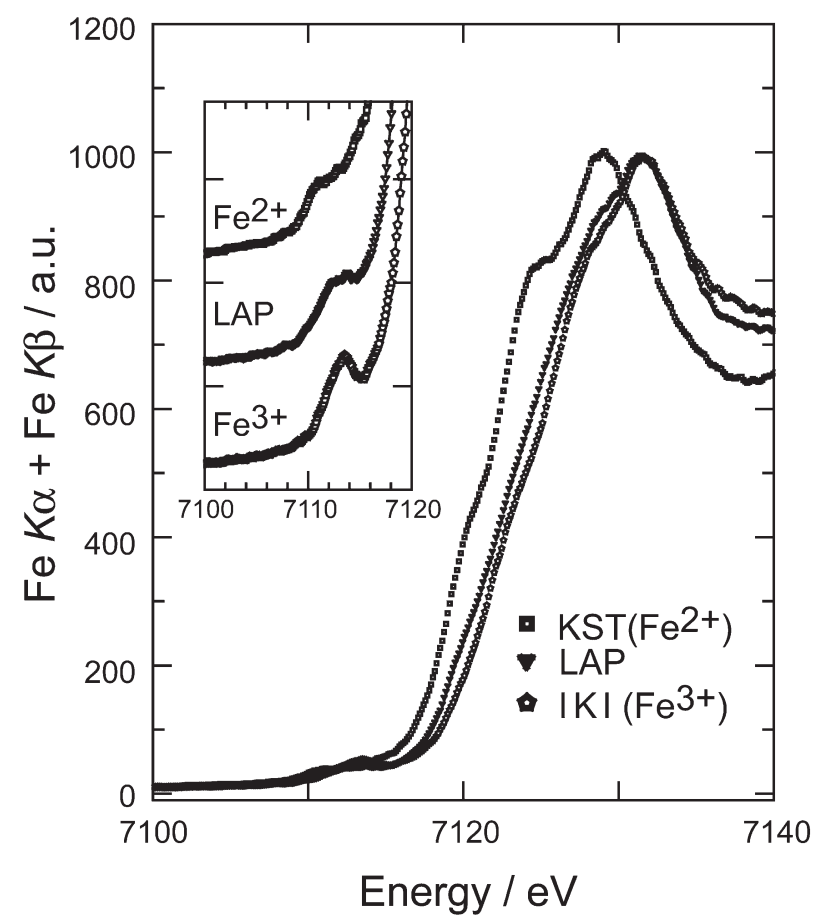

Figure 3. SR Fe-XANES spectra of LAP04840 hornblende and standard amphiboles measured at PF, KEK [KST: kaersutite from Kaersut, Greenland $\left(\mathrm{Fe}^{3+} / \Sigma \mathrm{Fe}=0.01\right)$ and IKI: kaersutite from Iki, Japan $\left.\left(\mathrm{Fe}^{3+} / \Sigma \mathrm{Fe}=0.93\right)\right]$. The SR beam size was $\sim 5 \mu \mathrm{m}$ in diameter. The inset shows the pre-edge peak region, showing that pre-edge peaks of the LAP04840 hornblende sample are near those of kaersutite from Iki Island.

9-10 wt $\% \mathrm{CaO}, 3 \mathrm{wt} \% \mathrm{Na}_{2} \mathrm{O}, 0.1-0.3 \mathrm{wt} \% \mathrm{~K}_{2} \mathrm{O}, 0.4-1.0$ wt $\% \mathrm{Cr}_{2} \mathrm{O}_{3}, 0.1-0.3 \mathrm{wt} \% \mathrm{NiO}$. Al and $\mathrm{Ti}$ are positively correlated and the cores are slightly $\mathrm{Al}^{-}$and $\mathrm{Ti}$-poorer than the rims although the difference is not significant. The total sum obtained from the electron microprobe analysis is $96-98 \mathrm{wt} \%$, suggesting the presence of $\mathrm{Fe}^{3+}$ and/or a hydroxyl group. The absence of $\mathrm{F}$ and $\mathrm{Cl}$ was also confirmed by both SEM analysis with the energy dispersive mode and electron microprobe analysis with the same mode. Plagioclase is essentially albitic $\left(\mathrm{An}_{8} \mathrm{Or}_{2}\right)$. Fe sulfide contains a significant amount of $\mathrm{Ni}$, and both pyrrhotite and pentlandite are present. A high content of $\mathrm{Ni}$ $(\sim 10 \mathrm{wt} \%)$ in pyrrhotite may be due to tiny pentlandite inclusions in pyrrhotite. Magnetite is $\mathrm{Cr}$-rich, containing $\sim 20 \mathrm{wt} \% \mathrm{Cr}_{2} \mathrm{O}_{3}$. Similar to hornblende, a low total sum ( $93 \mathrm{wt} \%)$ of magnetite by electron microprobe analysis suggests that a large amount of $\mathrm{Fe}$ is present as $\mathrm{Fe}^{3+}$. Biotite is nearly homogeneous: $39-40 \mathrm{wt} \% \mathrm{SiO}_{2}, 13 \mathrm{wt} \%$ $\mathrm{Al}_{2} \mathrm{O}_{3}, 1 \mathrm{wt} \% \mathrm{TiO}_{2}, 11-13 \mathrm{wt} \% \mathrm{FeO}$ (all $\mathrm{Fe}$ as $\mathrm{Fe}^{2+}$ ), $19-20 \mathrm{wt} \% \mathrm{MgO}, 2 \mathrm{wt} \% \mathrm{Na}_{2} \mathrm{O}, 6-7 \mathrm{wt} \% \mathrm{~K}_{2} \mathrm{O}, 0.7-1.0$ $\mathrm{wt} \% \mathrm{Cr}_{2} \mathrm{O}_{3}, 0.2-0.5 \mathrm{wt} \% \mathrm{NiO}$. The low total sum (93-96 $\mathrm{wt} \%$ ) by the electron microprobe analysis suggests the presence of a hydroxyl group as is the case for hornblende.

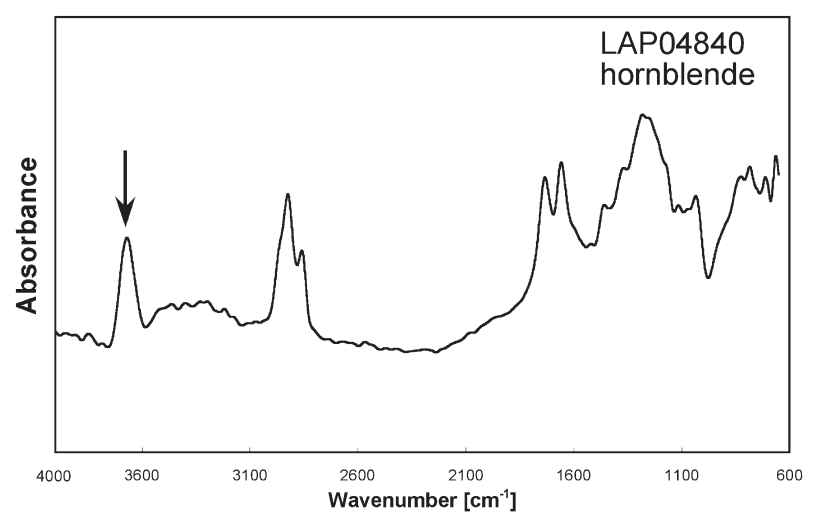

Figure 4. Micro-FT-IR spectrum of LAP04840 hornblende. The arrow indicates the absorption near $3650 \mathrm{~cm}^{-1}$ due to a strong $\mathrm{OH}$ bond.

\section{$\mathrm{Fe}^{3+} / \Sigma \mathrm{Fe}$ ratio and hydrous nature of hornblende}

The pre-edge signal at about $15-20 \mathrm{eV}$ below the main $K$-absorption edge of Fe XANES shifts toward the higher energy side as the $\mathrm{Fe}^{3+} / \Sigma \mathrm{Fe}$ ratio of minerals increases, indicating a linear relationship as a function of the $\mathrm{Fe}^{3+} / \Sigma \mathrm{Fe}$ ratio (Bajt et al., 1994, Wilke et al., 2001). In particular, the systematic Fe-XANES spectra for minerals clearly suggest that the $\mathrm{Fe}^{3+} / \Sigma \mathrm{Fe}$ ratio can be determined with an accuracy of $\pm 10 \mathrm{~mol} \%$ when the local coordination environment around $\mathrm{Fe}$ is given (Wilke et al., 2001). Figure 3 shows the Fe XANES profiles of the LAP04840 hornblende together with standard amphiboles (KST: $\mathrm{Fe}^{3+} / \Sigma \mathrm{Fe}$ $=0.01$ and IKI: $\mathrm{Fe}^{3+} / \Sigma \mathrm{Fe}=0.93$ ) observed at the $\mathrm{Fe} K$-absorption edge. The inset in Figure 3 shows the pre-edge peak region, which was used to estimate the $\mathrm{Fe}^{3+} / \Sigma \mathrm{Fe}$ ratio of LAP04840 hornblende. Figure 3 clearly indicates that the main-absorption edge and pre-edge peaks of the LAP04840 hornblende sample are quite near those of kaersutite from Iki Island, suggesting the overall preference of $\mathrm{Fe}^{3+}$ rather than $\mathrm{Fe}^{2+}$. The estimated $\mathrm{Fe}^{3+} / \Sigma \mathrm{Fe}$ ratio is 0.6 .

The micro-FT-IR analysis of LAP04840 hornblende confirms the presence of a hydroxyl group as is suggested by clear absorption at $3600-3700 \mathrm{~cm}^{-1}$ with a strong hydroxyl bond (e.g., Skogby and Rossman, 1991; Hawthorne et al., 2007) (Fig. 4). A similar result was obtained by Klima et al. (2007).

\section{Chemical formula of hornblende}

The combined electron microprobe, synchrotron $\mathrm{Fe}^{-}$ XANES, and micro-FT-IR analyses could offer an accurate chemical formula for the LAP08480 hornblende. The XANES analysis confirms the presence of $\mathrm{Fe}^{3+}$ in horn- 
Table 2. Structural analysis of the hornblende sample in LAP04840

\begin{tabular}{|c|c|}
\hline $\begin{array}{l}\text { Structural model } \\
\text { EPMA }\end{array}$ & $\begin{array}{l}\left(\mathrm{Na}_{0.76}\right)\left(\mathrm{Ca}_{1.46} \mathrm{Fe}_{0.08} \mathrm{Na}_{0.46}\right)\left(\mathrm{Mg}_{3.67} \mathrm{Fe}_{1.33}\right)\left(\mathrm{Si}_{7.04} \mathrm{Al}_{0.96}\right) \mathrm{O}_{22}(\mathrm{OH})_{2} \\
\left(\mathrm{Na}_{0.40} \mathrm{~K}_{0.04}\right)\left(\mathrm{Ca}_{1.46} \mathrm{Mn}_{0.02} \mathrm{Fe}^{2+}{ }_{0.06} \mathrm{Na}_{0.46}\right) \\
\quad\left(\mathrm{Mg}_{3.60} \mathrm{Fe}^{3+}{ }_{0.75} \mathrm{Fe}^{2+}{ }_{0.42} \mathrm{Cr}_{0.08} \mathrm{Al}_{0.07} \mathrm{Ti}_{0.05}\right)\left(\mathrm{Si}_{7.02} \mathrm{Al}_{0.98}\right) \mathrm{O}_{22}(\mathrm{OH})_{2} \\
\text { 856.4(structural model) :849.4(electron microprobe) }\end{array}$ \\
\hline Wavelength & $0.71069 \AA$ \\
\hline Device & Rigaku RAPID \\
\hline Method & Oscillation \\
\hline Crystal system & Monoclinic \\
\hline Space group & $C 2 / m$ \\
\hline Cell constants & $a=9.7957(9) \AA, b=18.0788(12) \AA, c=5.2949(5) \AA, \beta=104.747(3)^{\circ}$ \\
\hline Volume & $849.47(1) \AA^{3}$ \\
\hline Density (calculated) & $3.137 \mathrm{Mg} / \mathrm{m}^{3}$ \\
\hline Absorption coefficient & $2.361 \mathrm{~mm}^{-1}$ \\
\hline Crystal size & $0.08 \times 0.10 \times 0.14 \mathrm{~mm}$ \\
\hline Theta range & 2.26 to $30.49^{\circ}$ \\
\hline Index ranges & $-13<=h<=13,-25<=k<=24,-6<=l<=7$ \\
\hline Measured reflections & 4555 \\
\hline$R_{\text {int }} / / R_{\text {sigma }}$ & $0.0334 / 0.0350$ \\
\hline Data / parameters & $1410 / 103$ \\
\hline Godness-of-fit on $F^{2}$ & 1.242 \\
\hline$R$ indices $[I>2 \sigma(I)]$ & $R 1=0.0373, w R 2=0.0678$ \\
\hline$R$ indices (all data) & $R 1=0.0616, w R 2=0.1101$ \\
\hline Diff. peak and hole & 1.51 and -0.58 e. $\AA^{-3}$ \\
\hline
\end{tabular}

blende, which gives a $\mathrm{Fe}^{3+} / \Sigma \mathrm{Fe}$ ratio of $\sim 0.6$ (Fig. 3). Unit formulae were calculated using the $\mathrm{Fe}^{3+} / \Sigma \mathrm{Fe}$ ratio of 0.6 and normalized to $24(\mathrm{O}, \mathrm{OH})$ assuming $\mathrm{OH}=2.0 \mathrm{apfu}$ (atom per formula unit) as suggested by the micro-FT-IR measurement. By averaging the measured chemical compositions at 70 separate positions of several different hornblende grains, we arrived at the chemical composition of the present hornblende sample as shown in Table 1. The structural formula of the LAP04840 hornblende is thus given as $\left(\mathrm{Na}_{0.40} \mathrm{~K}_{0.04}\right)\left(\mathrm{Ca}_{1.46} \mathrm{Mn}_{0.02} \mathrm{Fe}_{0.06}^{2+} \mathrm{Na}_{0.46}\right)\left(\mathrm{Al}_{0.08}\right.$ $\left.\mathrm{Fe}_{0.43}^{2+} \mathrm{Fe}_{0.75}^{3+} \mathrm{Cr}_{0.08} \mathrm{Mg}_{3.60}\right)\left(\mathrm{Si}_{7.02} \mathrm{Al}_{0.98}\right) \mathrm{O}_{22}(\mathrm{OH})_{2}$, which corresponds to the general chemical formula of the amphibole group $\left[\mathrm{AB}_{2} \mathrm{C}_{5} \mathrm{~T}_{8} \mathrm{O}_{22} \mathrm{~W}_{2}\right.$, where $\mathrm{A}=\mathrm{Na}, \mathrm{K} ; \mathrm{B}=\mathrm{Ca}, \mathrm{Na}$, $\mathrm{Fe}^{2+}, \mathrm{Mn}^{2+} ; \mathrm{C}=\mathrm{Mg}, \mathrm{Fe}^{3+}, \mathrm{Fe}^{2+}, \mathrm{Cr}^{3+}, \mathrm{Al} ; \mathrm{T}=\mathrm{Si}, \mathrm{Al} ; \mathrm{W}=$ $(\mathrm{OH}), \mathrm{F}, \mathrm{Cl}, \mathrm{O}^{2-}$.

\section{Crystal structure of hornblende}

The hornblende structure indicates 15 independent atomic sites in a unit cell including the hydrogen position. There are two distinct tetrahedrally coordinated sites in the structure. The T(1) site is coordinated by three bridging and one non-bridging oxygens, and the other T(2) site is coordinated by two bridging oxygens and two non-bridging oxygens. These structural features cause very strong cation ordering between these T(1) and T(2) sites. Nevertheless, the $\mathrm{X}$-ray scattering factors of $\mathrm{Al}$ and $\mathrm{Si}$ are almost similar, while it is impractical to try and derive site populations directly by scattering refinement. Instead, the variation in mean interatomic distance around these sites was employed in order to assign $\mathrm{Al}$ and $\mathrm{Si}$ site populations (Hawthorne and Grundy, 1977). As for the three octahedral sites of $\mathrm{M}(1), \mathrm{M}(2)$, and $\mathrm{M}(3)$, their scattering species were considered as $\mathrm{Fe}$ and $\mathrm{Mg}$ since contents of other elements such as $\mathrm{Ti}, \mathrm{Mn}, \mathrm{Cr}$, and $\mathrm{Al}$ are very small to be analyzed separately with enough accuracy. The site occupancies for these octahedral sites were refined with a restraint that the numbers of $\mathrm{Fe}$ and $\mathrm{Mg}$ were considered as 2.64 apfu $\left(=\mathrm{Fe}^{2+}+\mathrm{Fe}^{3+}+\mathrm{Ti}+\mathrm{Cr}\right)$ and 7.36 apfu $(=\mathrm{Mg}+\mathrm{Al})$, respectively. The $\mathrm{C}$-group cation sum in excess of 5.0 apfu was usually assigned as $\mathrm{Mn}^{2+}$ or $\mathrm{Fe}^{2+}$ at the $\mathrm{M}(4)$ site, and then the population of the $\mathrm{M}(4)$ site was fixed as $1.46 \mathrm{Ca}, 0.06 \mathrm{Fe}^{2+}, 0.02 \mathrm{Mn}^{2+}$, and $0.46 \mathrm{Na}$. The scattering factor for minor $\mathrm{Mn}$ is also approximated by $\mathrm{Fe}$ for the $\mathrm{M}(4)$ site. Excess $\mathrm{Na}$ and $\mathrm{K}$ were assigned to the A site. Several cycles of full matrix least-squares refinement resulted in convergence at an $R$ factor of 5.5\% for an isotropic thermal model. The possible hydrogen position $\mathrm{H}(0.198,0,0.755)$ was revealed in the difference Fourier maps and was subsequently considered. The positional disorder for the A site in the mirror plane was clearly detected at this stage. Therefore, a structural model employing the harmony of $\mathrm{A}(\mathrm{m})$ and $\mathrm{A}(2)$ sites was introduced here, and their occupations were refined by using the scattering factor of $\mathrm{Na}$. An anisotropic thermal model was introduced except for the $\mathrm{H}, \mathrm{A}(\mathrm{m})$, and $\mathrm{A}(2)$ sites, and full matrix least-squares refinement of all variables converged to $R$ indices of $3.38 \%$ for the observed 
Table 3. Atomic positions and equivalent isotropic temperature factors for the hornblende sample in LAP04840

\begin{tabular}{llllll}
\hline Site & Site occupancy & $x$ & $y$ & $z$ & $U_{\text {eq }}$ \\
\hline $\mathrm{T}(1)$ & $\mathrm{Si} / \mathrm{Al}=0.76 / 0.24^{*}$ & $0.28363(8)$ & $0.08459(4)$ & $0.29706(15)$ & $0.00780(18)$ \\
$\mathrm{T}(2)$ & $\mathrm{Si}=1.0$ & $0.29042(8)$ & $0.17155(4)$ & $0.80370(15)$ & $0.00841(17)$ \\
$\mathrm{O}(1)$ & 1.0 & $0.1107(2)$ & $0.08594(9)$ & $0.2179(4)$ & $0.0091(4)$ \\
$\mathrm{O}(2)$ & 1.0 & $0.11906(19)$ & $0.17024(10)$ & $0.7233(4)$ & $0.0098(4)$ \\
$\mathrm{O}(3)$ & 1.0 & $0.1078(3)$ & 0.0 & $0.7166(5)$ & $0.0123(6)$ \\
$\mathrm{O}(4)$ & 1.0 & $0.3650(2)$ & $0.24921(10)$ & $0.7879(4)$ & $0.0147(4)$ \\
$\mathrm{O}(5)$ & 1.0 & $0.3497(2)$ & $0.13599(11)$ & $0.0976(4)$ & $0.0143(4)$ \\
$\mathrm{O}(6)$ & 1.0 & $0.3471(2)$ & $0.11772(10)$ & $0.5955(4)$ & $0.0130(4)$ \\
$\mathrm{O}(7)$ & 1.0 & $0.3444(3)$ & 0.0 & $0.2840(6)$ & $0.0160(6)$ \\
$\mathrm{M}(1)$ & $\mathrm{Fe} / \mathrm{Mg}=0.391 / 0.609(3)$ & 0.0 & $0.08336(5)$ & $1 / 2$ & $0.0110(2)$ \\
$\mathrm{M}(2)$ & $\mathrm{Fe} / \mathrm{Mg}=0.113 / 0.887(3)$ & 0.0 & $0.17712(6) 0.0$ & & $0.0088(3)$ \\
$\mathrm{M}(3)$ & $\mathrm{Fe} / \mathrm{Mg}=0.312 / 0.688(6)$ & 0.0 & 0.0 & 0.0 & $0.0092(4)$ \\
$\mathrm{M}(4)$ & $\mathrm{Fe} / \mathrm{Ca} / \mathrm{Na}=0.04 / 0.73 / 0.23$ & $1 / 2$ & $0.22453(5)$ & $1 / 2$ & $0.0141(2)$ \\
$\mathrm{A}(\mathrm{m})$ & $\mathrm{Na}=0.28(1)$ & $0.4349(10)$ & 0.0 & $0.874(2)$ & $0.036(3)$ \\
$\mathrm{A}(2)$ & $\mathrm{Na}=0.20(2)$ & $1 / 2$ & 0.0 & 0.0 & $0.065(10)$ \\
$\mathrm{H}$ & 1.0 & 0.1984 & 0.0 & 0.7545 & $0.049(19)$ \\
\hline
\end{tabular}

* See the text.

Table 4. Anisotropic temperature factors for the hornblende sample in LAP04840

\begin{tabular}{lllllll}
\hline Site & $U_{11}$ & $U_{22}$ & $U_{33}$ & $U_{23}$ & $U_{13}$ & $U_{12}$ \\
\hline $\mathrm{T}(1)$ & $0.0082(4)$ & $0.0073(3)$ & $0.0081(4)$ & $-0.0004(3)$ & $0.0025(3)$ & $-0.0007(3)$ \\
$\mathrm{T}(2)$ & $0.0090(4)$ & $0.0084(3)$ & $0.0081(4)$ & $-0.0001(3)$ & $0.0026(3)$ & $-0.0012(3)$ \\
$\mathrm{O}(1)$ & $0.0094(9)$ & $0.0102(9)$ & $0.0077(9)$ & $0.0000(7)$ & $0.0021(8)$ & $-0.0001(7)$ \\
$\mathrm{O}(2)$ & $0.0072(9)$ & $0.0118(9)$ & $0.0104(9)$ & $0.0005(7)$ & $0.0026(7)$ & $0.0004(7)$ \\
$\mathrm{O}(3)$ & $0.0100(14)$ & $0.0116(13)$ & $0.0147(15)$ & 0.0 & $0.0022(11)$ & 0.0 \\
$\mathrm{O}(4)$ & $0.0160(10)$ & $0.0105(9)$ & $0.0172(11)$ & $0.0000(8)$ & $0.0033(9)$ & $-0.0041(7)$ \\
$\mathrm{O}(5)$ & $0.0113(9)$ & $0.0185(10)$ & $0.0125(10)$ & $0.0062(8)$ & $0.0018(8)$ & $0.0001(7)$ \\
$\mathrm{O}(6)$ & $0.0108(10)$ & $0.0157(10)$ & $0.0129(10)$ & $-0.0036(8)$ & $0.0039(8)$ & $0.0012(7)$ \\
$\mathrm{O}(7)$ & $0.0140(14)$ & $0.0097(13)$ & $0.0237(17)$ & 0.0 & $0.0035(13)$ & 0.0 \\
$\mathrm{M}(1)$ & $0.0116(5)$ & $0.0140(4)$ & $0.0085(5)$ & 0.0 & $0.0045(4)$ & 0.0 \\
$\mathrm{M}(2)$ & $0.0094(6)$ & $0.0092(6)$ & $0.0084(6)$ & 0.0 & $0.0035(4)$ & 0.0 \\
$\mathrm{M}(3)$ & $0.0116(7)$ & $0.0070(6)$ & $0.0081(7)$ & 0.0 & $0.0010(5)$ & 0.0 \\
$\mathrm{M}(4)$ & $0.0137(4)$ & $0.0191(4)$ & $0.0125(5)$ & 0.0 & $0.0091(4)$ & 0.0 \\
\hline
\end{tabular}

reflections. Cell parameters and other information pertinent to the structural refinement are listed in Table 2. The final positional and thermal parameters are given in Tables 3 and 4.

\section{DISCUSSION}

\section{Structure of hornblende}

Single crystal X-ray diffraction of hornblende gives the following lattice constants: $a=9.7957(9) \AA, b=$ 18.0788(12) $\AA, c=5.2949(5) \AA, \beta=104.747(3)^{\circ} \quad$ (Table $2)$. Results of the electron microprobe analysis show the low level of tetrahedrally coordinated Al which is well supported by the relatively short distances of $[\mathrm{T}(1)-\mathrm{O}=$ $1.650 \AA]$ and $[\mathrm{T}(2)-\mathrm{O}=1.633 \AA]$. The averaged distances lead to an Al occupation of 0.24 and $0.00 \%$ for the $\mathrm{T}(1)$ and $\mathrm{T}(2)$ sites, respectively (Hawthorne and Grundy, 1977). The total tetrahedral Al indicated by these occupations is $0.96 \mathrm{Al}$ apfu. This value agrees well with the structural formula of $0.98 \mathrm{Al}$ obtained by the electron microprobe analysis. The preference of $\mathrm{Al}$ at the T(1) site is frequently discussed with reference to the significantly deficient bond valence sum for the $\mathrm{O}(4)$ site. In order to maintain the highest possible bond valence to $\mathrm{O}(4)$, the $\mathrm{T}(2)$ prefers a relatively short distance of $\mathrm{T}(2)-\mathrm{O}(4)=$ 1.595(2) $\AA$ together with the preference of $\mathrm{Si}$ at the expense of Al (Hawthorne, 1978).

The synchrotron Fe-XANES analysis for the present hornblende sample shows the predomination of the trivalent $\mathrm{Fe}^{3+}$ rather than divalent $\mathrm{Fe}^{2+}$. At the same time, the electron microprobe analysis shows the extremely small content of octahedral Al. These features are not common for ordinary terrestrial hornblende samples (Oberti et al., 
Table 5. Results of the site population analysis by using the observed interatomic distance

\begin{tabular}{lllll}
\hline Site & Structural analysis & Population model & $<\mathrm{M}-\mathrm{O}>$ calc. & $<\mathrm{M}-\mathrm{O}>$ obs. \\
\hline $\mathrm{M}(1)$ & $0.61 \mathrm{Mg}+0.39 \mathrm{Fe}$ & $0.61 \mathrm{Mg}+0.08 \mathrm{Fe}^{2+}+0.31 \mathrm{Fe}^{3+}$ & 2.069 & 2.069 \\
$\mathrm{M}(2)$ & $0.89 \mathrm{Mg}+0.11 \mathrm{Fe}$ & $0.89 \mathrm{Mg}+0.04 \mathrm{Fe}^{2+}+0.07 \mathrm{Fe}^{3+}$ & 2.081 & 2.081 \\
$\mathrm{M}(3)$ & $0.69 \mathrm{Mg}+0.31 \mathrm{Fe}$ & $0.69 \mathrm{Mg}+0.00 \mathrm{Fe}^{2+}+0.31 \mathrm{Fe}^{3+}$ & $2.061^{*}$ & 2.058 \\
\hline
\end{tabular}

* Analysis of the averaged distance of the M(3) site indicates the saturation of $\mathrm{Fe}^{3+}$.

1995; Hawthorne et al., 2007). The characteristic chemical composition for the octahedral sites of $\mathrm{M}(1), \mathrm{M}(2)$, and $\mathrm{M}(3)$ is well reproduced by the mean bond distances of $[\mathrm{M}(1)-\mathrm{O}]=2.069 \AA,[\mathrm{M}(2)-\mathrm{O}]=2.081 \AA$, and $\left[\mathrm{M}(3)^{-}\right.$ $\mathrm{O}]=2.058 \AA$. In particular, the distances of $[\mathrm{M}(1)-\mathrm{O}]$ and $[\mathrm{M}(3)-\mathrm{O}]$ are shorter than the corresponding ones found in the ordinary terrestrial hornblende samples. This reflects the feature that the small $\mathrm{Fe}^{3+}$ is predominantly located at these $\mathrm{M}(1)$ and $\mathrm{M}(3)$ sites. In the case of $\mathrm{M}(2)$ sites, the preference of $\mathrm{Mg}$ at the expense of $\mathrm{Al}$ supports the relatively large octahedral site among the three sites. In the previous study, the relationships between mean bond length and averaged ionic size for constituents were suggested to be almost linear in the clino-amphibole system (Hawthorne, 1978, 1983). This interesting discussion provided the regression equations for the mean bond distances and sum of ionic radii on a variety of amphibole samples. By using those regression linear models for the octahedral sites, site populations for the present hornblende sample was studied.

In the structural model obtained by single crystal $\mathrm{X}$-ray diffraction, the $\mathrm{M}(1), \mathrm{M}(2)$, and $\mathrm{M}(3)$ sites are occupied by $0.61 \mathrm{Mg}+0.39 \mathrm{Fe}, 0.89 \mathrm{Mg}+0.11 \mathrm{Fe}$, and $0.69 \mathrm{Mg}+0.31 \mathrm{Fe}$, respectively. Since the $\mathrm{Mg}$ content at each site can be fixed by structural analysis, the corresponding population for $\mathrm{Fe}^{2+}$ and $\mathrm{Fe}^{3+}$ is readily estimated to fulfill the observed mean bond distance by determining the ratios of $\mathrm{Fe}^{2+}$ and $\mathrm{Fe}^{3+}$. The results of the site population analysis with constraints of mean bond distances are given in Table 5, and the values indicate the overall preference of $\mathrm{Fe}^{3+}$ rather than $\mathrm{Fe}^{2+}$ in the octahedral sites.

The estimated site population in Table 5 leads to $\mathrm{Fe}^{3+} / \Sigma \mathrm{Fe}=0.82$, which is larger than $\mathrm{Fe}^{3+} / \Sigma \mathrm{Fe}=0.60$ obtained by the XANES analysis. The detected discrepancy may be partly attributed to the effects of small cations such as $\mathrm{Ti}, \mathrm{Cr}$, and $\mathrm{Al}$ in the octahedral sites and/or the underestimation of the experimental $\mathrm{Fe}^{3+} / \Sigma \mathrm{Fe}$ ratio. It should be noted that the observed averaged interatomic distances for octahedral sites clearly suggest the overall preference of $\mathrm{Fe}^{3+}$ over $\mathrm{Fe}^{2+}$ in the present hornblende sample.

The present chemical analysis indicates the distribution of $\mathrm{Na}$ and $\mathrm{Ca}$ with a small amount of $\mathrm{Mn}$ or $\mathrm{Fe}$ at the
$\mathrm{M}(4)$ site and - this information was introduced into the structural model. The M(4) site is surrounded by eight oxygens; nevertheless, the site's anion configuration is strongly dependent on its constituting elements. The coordination model with eight surrounding oxygens is usually employed for the description of the local coordination polyhedron of calcic-amphiboles. It is well known that the coordination features of the $\mathrm{M}(4)$ site with a large coordination polyhedron make them susceptible to the possible effects from the rest of the structure. The averaged distance of $[\mathrm{M}(4)-\mathrm{O}=2.506 \AA]$ indicates the good agreement with the previous analysis for the calcic-amphiboles (Hawthorne, 1983). The highest residual electron density can be observed near the M(4) site in the present analysis, and this may suggest the chemically disordered M(4) site.

As suggested by the previous studies on amphiboles, a structural model with positional disorder of the A-site cations in the mirror plane and along the two-fold axis is frequently utilized to explain the observed electron densities at the cavity between the back-to-back tetrahedral chains of the amphibole structure. The present analysis introduced the $\mathrm{A}(\mathrm{m})$ and $\mathrm{A}(2)$ sites with almost equal site occupancies of $\mathrm{Na}$ at the cavity. Since the concentration of $\mathrm{K}$ is very low in the present sample, the preference of $\mathrm{Na}$ and $\mathrm{K}$ for these sites could not be analyzed. The results of the present structural analysis indicate the distribution of $0.76 \mathrm{Na}$ apfu (8.4 electron pfu). This is larger than that obtained by the electron microprobe analysis (5.2 electron pfu). With this data, we could not identify the reason for the detected discrepancy for the A-site cations. Nevertheless, we believe that this discrepancy is attributed to the harmony of the cumulative errors in the chemical analysis and the not very reliable site occupancies for the split A-sites analyzed by X-rays (Hawthorne. 1983).

\section{Formation of hornblende}

Both olivine and pyroxene compositions of LAP04840 are in the range of $\mathrm{R}$ chondrites and distinct from other chondrite groups (e.g., Brearley and Jones, 1998). The completely equilibrated mineral compositions of olivine 
and pyroxene along with the presence of large albite grains and the typical metamorphosed texture of LAP04840 show that it is an R6 chondrite. However, the presence of abundant hornblende and rare biotite is quite unique among not only $\mathrm{R}$ chondrites but also asteroidal meteorites in general. Because they are replacing primary minerals in both chondrules and matrices, it is obvious that secondary alteration on the parent body formed these metamorphic minerals. The presence of these hydrous minerals suggests metamorphism under high pressure and an aqueous environment.

Because hornblende and plagioclase are in equilibrium in LAP04840, a geothermometer using chemical compositions of these two minerals by Holland and Blundy (1994) can be employed. It gives an equilibration temperature of $670-690{ }^{\circ} \mathrm{C}$ for LAP04840 phases. This temperature bears some uncertainty in the present case because LAP04840 hornblende contains a high $\mathrm{Fe}^{3+}$ composition as demonstrated by XRD and micro-XANES analyses. However, this temperature is consistent with other reports (McCanta et al., 2006; Treiman et al., 2007), which estimated $T$ to be $\sim 600-800{ }^{\circ} \mathrm{C}$. The mineral assemblages in LAP04840 are not directly applicable for the known geobarometers. If we apply a barometer using the $\mathrm{Al}$ content of hornblende, we get $P=0.11 \pm 0.06 \mathrm{GPa}$ (Anderson and Smith, 1995). This barometer bears uncertainty because it is usually applicable for granite in specific conditions, which requires a phase assemblage of hornblende + biotite + plagioclase $+\mathrm{K}$-feldspar + quartz + sphene $+\mathrm{Fe}$-Ti oxides + melt + fluid phase (Anderson and Smith, 1995). In LAP04840, K-feldspar, quartz, and sphene are absent. The Al-Ti-thermobarometer of $\mathrm{Ca}$-amphibole by Ernst and Liu (1998) is established for a natural mid-ocean ridge basalt (MORB) composition and can be better applied for the LAP04840 mineral assemblage. This barometer using the $\mathrm{Al}$ contents of LAP04840 hornblende gives a $P$ value of about $0.1 \mathrm{GPa}$ at $T=680{ }^{\circ} \mathrm{C}$, which is close to the estimate using the Anderson and Smith (1995) barometer. The low $\mathrm{Ti}$ content $\left(\mathrm{TiO}_{2} \sim 0.5 \mathrm{wt} \%\right)$ of LAP04840 hornblende leads to extremely high pressure exceeding $0.5 \mathrm{GPa}$ at $T=680{ }^{\circ} \mathrm{C}$, which is not likely the case for LAP04840. Treiman et al. (2007) estimated that $P_{\mathrm{H}_{2} \mathrm{O}}$ is restricted to $\sim 0.01-0.07 \mathrm{GPa}$ at $T=655^{\circ} \mathrm{C}$ based on the mineral assemblage of biotite and enstatite together with some other restrictions using the calculation by THERMOCALC (Powell et al., 1998). Although our estimate gives slightly different temperature and pressure conditions, it is obvious that metamorphism took place under a high-pressure aqueous condition. The oxygen fugacity during the formation of LAP04840 was probably near the QFM (quartz-fayalite-magnetite) buffer because of the presence of abundant $\mathrm{Fe}^{3+}$ in hornblende, biotite, and Cr-rich magnetite. Dyar et al. (2007) estimated the oxygen fugacity from olivine-orthopyroxene-spinel equilibria by using the QUILF calibration, and they obtained $\log f_{\mathrm{O}_{2}}=\mathrm{QFM} \pm 0.75$.

As LAP04840 has a similar oxygen isotope composition to other R chondrites (Antarct. Meteorite Newslett., 2006), there is no doubt that it originated from the same parent body as other R chondrites. Because primary phases such as olivine and pyroxene are anhydrous, it is likely that LAP04840 was originally formed under a dry condition similar to other R chondrites. If LAP04840 was originally formed under a wet condition, primary olivine and pyroxene would be altered into serpentine or saponite. In order to achieve a secondary high-pressure hydrous condition, two scenarios could be considered. One is that water was brought by some exogenic mechanism after the formation of the LAP04840 parent body and then hot, hydrous, high-pressure metamorphism took place. Treiman et al. (2007) reported that the $\mathrm{D} / \mathrm{H}$ ratios of hydrogen in LAP04840 amphibole and biotite were $\delta \mathrm{D}=3660 \pm$ $75 \%$ and $\delta \mathrm{D}=2930 \pm 100 \%$, respectively, and pointed out that the very high $\delta \mathrm{D}$ value for LAP04840 hydrogen is unlike nearly all known hydrogen reservoirs (Robert et al., 2000). Impact by a water (and D)-rich body such as a carbonaceous chondrite or comet could result in metamorphism, but it is unlikely that such high pressure could be achieved and lasted for a certain period to crystallize large hornblende grains. The other scenario, which is more likely, is that metamorphism took place in the LAP04840 parent body at depth. Some source of the $\mathrm{D}$-rich water accreted with the $\mathrm{R}$ chondrite matrix and the parent body was heated from the center outwards. $\mathrm{H}_{2} \mathrm{O}$ would react with silicates and magnetite to form areas similar to upper amphibolite faces in terrestrial rocks, corresponding to LAP04840. If this is the case, it is likely that the size of the $\mathrm{R}$ chondrite parent body was large enough to produce such metamorphism, which achieved $T=670-690{ }^{\circ} \mathrm{C}$ and $P=\sim 0.1 \mathrm{GPa}$. It would be difficult to excavate such a deep zone in the parent body onto the surface by a single impact event. Therefore, multiple impact events are considered for the $\mathrm{R}$ chondrite parent body. This is consistent with the observation that most $\mathrm{R}$ chondrites are breccias (e.g., Brearley and Jones, 1998). Dixon et al. (2003) measured Ar-Ar ages of some R chondrites and obtained a range of 4.3-4.47 Ga. They suggested relatively early $(\sim 4.47 \mathrm{Ga})$ impact events and breccia formation of the R chondrite parent body. LAP04840 is the only $\mathrm{R}$ chondrite known to date that shows a large degree of amphibolitization metamorphism although there are many equilibrated $\mathrm{R}$ chondrites. However, most equilibrated $\mathrm{R}$ chondrites are petrologic types 4 and 5 , while type 6 samples are found only in the clasts of brecciated 
$\mathrm{R}$ chondrites and do not contain hydrous phases (Meteoritical Bulletin Database, 2008). Therefore, such an aqueous environment might be only locally present at the extremely deep zone of the R chondrite parent body, and LAP04840 is the only example of an R chondrite at present that was excavated from such a deep zone.

\section{CONCLUSIONS}

(1) We analyzed a LAP04840 meteorite ( $\sim 50$ g) recently recovered from Antarctica and confirmed that it is an R6 chondrite with abundant hornblende. This is the first meteorite known to date which contains abundant large amphibole grains. All mineral phases are uniform in composition. Olivine and pyroxenes are $\mathrm{Fe}^{-}$ rich, and plagioclase is albitic.

(2) Electron microprobe analysis together with synchrotron Fe XANES measuring $\mathrm{Fe}^{3+} / \Sigma \mathrm{Fe}(\sim 0.6)$ and micro-FT-IR analyses measuring the abundance of a hydroxyl group gave the structural formula of LAP 04840 hornblende as $\left(\mathrm{Na}_{0.40} \mathrm{~K}_{0.04}\right)\left(\mathrm{Ca}_{1.46} \mathrm{Mn}_{0.02} \mathrm{Fe}_{0.06}^{2+} \mathrm{Na}_{0.46}\right)$ $\left(\mathrm{Al}_{0.08} \mathrm{Fe}_{0.43}^{2+} \mathrm{Fe}_{0.75}^{3+} \mathrm{Cr}_{0.08} \mathrm{Mg}_{3.60}\right)\left(\mathrm{Si}_{7.02} \mathrm{Al}_{0.98}\right) \mathrm{O}_{22}(\mathrm{OH})_{2}$.

(3) Single crystal $\mathrm{X}$-ray diffraction analysis led to the successful refinement of LAP04840 hornblende with $R$ indices of $3.38 \%$ for observed reflections. Low level of tetrahedrally coordinated Al obtained by the electron microprobe analysis is supported by the relatively short distances of $[\mathrm{T}(1)-\mathrm{O}=1.650 \AA]$ and $[\mathrm{T}(2)-\mathrm{O}=$ $1.633 \AA]$. The distances of $[\mathrm{M}(1)-\mathrm{O}=2.069 \AA]$ and $[\mathrm{M}(3)-\mathrm{O}=2.058 \AA]$ are shorter than that of $[\mathrm{M}(2)-\mathrm{O}$ $=2.081 \AA]$ because a small $\mathrm{Fe}^{3+}$ cation is predominantly located at these $\mathrm{M}(1)$ and $\mathrm{M}(3)$ sites. These lengths are shorter than the corresponding ones found in the ordinary terrestrial hornblende samples. The $\mathrm{M}(1), \mathrm{M}(2)$, and $\mathrm{M}(3)$ sites are occupied by $0.61 \mathrm{Mg}+$ $0.39 \mathrm{Fe}, 0.89 \mathrm{Mg}+0.11 \mathrm{Fe}$, and $0.69 \mathrm{Mg}+0.31 \mathrm{Fe}$, respectively.

(4) The occurrence of hornblende indicates a secondary high-pressure aqueous alteration in the LAP04840 parent body. The mineral assemblage and compositions found in LAP04840 implies an equilibration $T$ of $670-690{ }^{\circ} \mathrm{C}$ and $P$ of $\sim 0.1 \mathrm{GPa}$. We believe metamorphism took place in the LAP04840 parent body at depth. $\mathrm{H}_{2} \mathrm{O}$ would react with silicates and magnetite to form areas similar to upper amphibolite faces in terrestrial rocks. It is likely that the size of the $\mathrm{R}$ chondrite parent body was large enough to produce such metamorphism although such an aqueous environment might be only locally present at the deep interior of the parent body.

\section{ACKNOWLEDGMENTS}

We thank MWG for supplying the LAP04840 sample for this study. We are indebted to Mr. H. Yoshida for technical assistance during the electron beam analyses and Prof. A. Iida for the synchrotron XANES analysis. Discussion with Prof. K. Ozawa was also helpful. The manuscript was improved by constructive reviews from two anonymous reviewers. Electron microscopy was performed in the Electron Microbeam Analysis Facility for Mineralogy at the Department of Earth and Planetary Science, University of Tokyo. The micro-XANES study was performed under the approval of the Photon Factory Program Advisory Committee (Proposal No. 2005G150). This work was supported in part by a Grant-in-Aid for Young Scientists (B) by the Japanese Ministry of Education, Culture, Sports, Science and Technology (No. 18740334 and 20740305) (TM).

\section{REFERENCES}

Anderson, J.L. and Smith, D.R. (1995) The effects of temperature and $\mathrm{fO}_{2}$ on the $\mathrm{Al}$-in-hornblende barometer, American Mineralogist, 80, 549-559.

Antarctic Meteorite Newsletter (2006) Satterwhite, C. and Righter, K. Eds. The Meteorite Working Group, NASA, Texas, 29-1.

Bajt, S., Sutton, S.R. and Delaney, J.S. (1994) X-ray microprobe analysis of iron oxidation states in silicates and oxides using $\mathrm{X}$-ray absorption near edge structure (XANES). Geochimica et Cosmochimica Acta, 58, 5209-5214.

Brearley, A.J. and Jones, R.H. (1998) Chondritic meteorites. In Planetary Materials (Papike, J.J. Ed.). Reviews in Mineralogy 36, Mineralogical Society of America, Chantilly, Virginia, 3-1 to 3-398.

Dixon, E.T., Bogard, D.D. and Garrison, D.H.(2003) ${ }^{39} \mathrm{Ar}^{-40} \mathrm{Ar}$ chronology of $\mathrm{R}$ chondrites. Meteoritics and Planetary Science, 38, 341-355.

Dyar, M.D., McCanta, M.C., Treiman, A.H., Sklute, E.C. and Marchand, G.J. (2007) Mössbauer Spectroscopy and Oxygen Fugacity of Amphibole-bearing R-Chondrite LAP04840. Lunar and Planetary Science, XXXVIII, Abstract \#2047, Lunar and Planetary Institute, Houston (CD-ROM).

Ernst, W.G. and Liu, J. (1998) Experimental phase-equilibrium study of $\mathrm{Al}^{-}$and Ti-contents of calcic amphibole in MORB - A semiquantitative thermometer. American Mineralogist, 83, 952-969.

Hawthorne, F.C. (1978) The crystal chemistry of the amphiboles. VIII. The crystal structure and the site chemistry of fluor-riebeckite. Canadian Mineralogist, 16, 187-194.

Hawthorne, F.C. (1983) The crystal chemistry of the amphiboles. Canadian Mineralogist, 21, 173-480.

Hawthorne, F.C. and Grundy, H.D. (1977) The crystal chemistry of the amphiboles. III: Refinement of the crystal structure of a sub-silicic hastingsite. Mineralogical Magazine, 41, 43-50.

Hawthorne, F.C., Oberti, R., Ventura, G.D. and Mottana, A. (2007) Amphiboles: Crystal chemistry, occurrence, and health issues. pp. 546, Reviews in Mineralogy and Geochemistry, Mineralogical Society of America, Chantilly, Virginia. 
Higashi, T. (1995) ABSCOR. Rigaku Corporation, Tokyo Japan.

Holland, T. and Blundy, J. (1994) Non-ideal interactions in calcic amphiboles and their bearing on amphibole plagioclase thermometry. Contributions to Mineralogy and Petrology, 116, 433-447.

Iida, A. (1997) X-ray spectrometric applications of a synchrotron X-ray microbeam. X-ray Spectrometry, 6, 359-363.

International Tables for Crystallography Volume C (1992) Dordrecht: Kluwer Academic Publishers.

Johnson, M.C., Rutherford, M.J. and Hess, P.C. (1991) Chassigny petrogenesis: Melt compositions, intensive parameters, and water contents of Martian(?) magmas. Geochimica et Cosmochimica Acta, 55, 349-36.

Kallemeyn, G.W., Rubin, A.E. and Wasson, J.T. (1996) The compositional classification of chondrites: VII. The R chondrite group. Geochimica et Cosmochimica Acta, 60, 2243-2256.

Klima, R., Pieters, C.M., Sunshine, J.M., Hiroi, T., Bishop, J.L., Lane, M.D., Dyar, M.D. and Treiman, A.H. (2007) Coordinated spectroscopic and petrologic investigation of LAP 04840: First results of infrared, thermal and Raman spectroscopy. Lunar and Planetary Science, XXXVIII, Abstract \#1710, Lunar and Planetary Institute, Houston (CD-ROM).

McCanta, M.C., Treiman, A.H. and Essene, E. (2006) LAP 04840: An amphibole-bearing R chondrite. Meteoritics and Planetary Science, 41, Supplement, A118.

McSween, H.Y., Jr. (2002) The rocks of Mars, from far and near. Meteoritics and Planetary Science, 37, 7-25.

Meteoritical Bulletin Database (2008) http://tin.er.usgs.gov/meteor/metbull.php.

Mikouchi, T. and Miyamoto, M. (2000) Micro Raman spectroscopy of amphibole and pyroxene in martian meteorites Zagami and Lewis Cliff 88516. Meteoritics and Planetary Science, $35,155-159$.

Mikouchi, T., Ota, K., Makishima, J., Monkawa, A. and Sugiyama K. (2007) Mineralogy and crystallography of LAP 04840: Implications for metamorphism at depth in the $\mathrm{R}$ chondrite parent body. Lunar and Planetary Science, XXXVIII, Abstract \#1928, Lunar and Planetary Institute, Houston (CDROM).

Monkawa, A., Mikouchi, T., Koizumi, E., Sugiyama, K. and Miyamoto, M. (2006) Determination of the Fe oxidation state of the Chassigny kaersutite: A microXANES spectroscopic study. Meteoritics and Planetary Science, 41, 1321-1329.

Oberti, R., Ungaretti, L., Cannillo, E., Hawthorne, F.C., Memmi, I. (1995) European Journal of Mineralogy, 7, 1049-1063.

Powell, R., Holland, T.J.B. and Worley, B. (1998) Calculating phase diagrams involving solid solutions via non-linear equations, with examples using THERMOCALC. Journal of Metamorphic Geology, 16, 577-588.

Robert, F., Gautier, D. and Dubrulle, B. (2000) The solar system $\mathrm{D} / \mathrm{H}$ ratio: Observations and theories. Space Science Reviews, 92, 201-224.

Sheldrick, G.M. (1997) SHELXL-97. Program for Crystal Structure Refinement. University of Göttingen, Germany.

Skogby, H. and Rossman, G.R. (1991) The intensity of amphibole $\mathrm{OH}$ bands in the infrared absorption spectrum. Physics and Chemistry of Minerals, 18, 64-68.

Treiman, A.H., Alexander, C.M.O'd., Essene, E.J. and McCanta, M.C. (2007) The amphibole-phlogopite R-Chondrite LAP 04840: Hot hydration by heavy $\mathrm{H}_{2} \mathrm{O}$. Lunar and Planetary Science, XXXVIII, Abstract \#1481, Lunar and Planetary Institute, Houston (CD-ROM).

Wilke, M., Farges, F., Petit, P.-E., Brown Jr.,G.E. and Martin, F. (2001) Oxidation state and coordination of Fe in minerals: an Fe K-XANES spectroscopic study. American Mineralogist, $86,714-730$.

Manuscript received September 3, 2008

Manuscript accepted January 22, 2009

Published online June 13, 2009

Manuscript handled by Akira Yoshiasa 